\title{
AN ANALYSIS OF THE IMPLEMENTATION OF PROBLEM BASED LEARNING IN LEARNING ENGLISH AT THE XI GRADE SCIENCE CLASS OF SMA NEGERI 1 SINGARAJA IN THE ACADEMIC YEAR 2015/2016
}

\author{
Apriliadewi, P.A.R. \\ English Education Department, Ganesha University of Education \\ e-mail: ayureza48@yahoo.co.id
}

\begin{abstract}
This research aimed to describe the implementation of problem based learning science in learning English at the XI grade science class of SMA Negeri 1 Singaraja. The subjects of this research were an English teacher and 32 students of class XI MIA 6 in SMA N 1 Singaraja. Research methods used were observation, interview and questionnaire. The results of this research show that: (1) the implementation of problem based learning in learning English in XI MIA 6 class of SMA N 1 Singaraja has been implemented based on the phases of this model; (2)The problems faced by the English teacher during the implementation of problem based learning are the teacher is difficult to manage the learning time, determine the problem which is related to students' characteristics, and cannot check all of the students' work because of the big number of the students'; (3)The main problem faced by the students during the implementation of this model was they cannot improve in collaborative learning in solving the problem. However, the students give a positive response to the implementation of problem based learning in their class.
\end{abstract}

Keywords: problem based learning, English learning

\section{INTRODUCTION}

Education confronted with several challenges in the development of the education improvement (Sukraningsih, 2015). Therefore, education is expected to create students who have a good competency in thinking and communicating. Students who have a good competency in thinking, they can have knowledge, critical and creative thinking skill (Arends, 2008). Based on the syllabus of the curriculum 2013, the students are expected to be able to process the learning activity well, reason and express opinions related to the development of the learning in school independently. Education is also expected to enable the students to act effectively and creatively.

In the scope of Education, teaching is a process of classroom management including the interaction between teachers and students, therefore the students can express their opinion and respond what is conveyed by the teacher during learning activities (Powell, 2013). The learning process more emphasizes on the teacher's efforts to transfer knowledge and coach the learners in classroom. In line with curriculum 2013, education in Indonesia uses a scientific approach in order to train students skills (Kemendikbud,2014). To apply the scientific approach, the teacher needs the model of learning. One of the models or strategies that can use is Problem Based Learning.

Problem Based Learning model is one of the three models of learning related to scientific approach. According to Mathews (2007), in Problem Based Learning the 
teacher acts as a coach or facilitator of activities which are carried out the students. The teacher does not easy to present information or directly control the learning process. Instead, the teacher provides the students the appropriate problems to work in learning process, assists them in identifying material, givesfeedback and support during the problem solving process.

According to Kadir (2013) Problem Based Learning is a model that is suitable for pedagogic activities. That is because students are required to be active in communicating pedagogical activities. By implementing this model, students can express their opinions and their ideas. From both theories, Problem Based Learning is the model that is used to make the students active in learning and have critical thinking in learning process.

There are some characteristics of Problem Based Learning which are expected to be implemented in the classroom (Kemendikbud,2013). First, it strongly maintains selflearning (self directed learning). Second, the problems used cannot be well-structured. Third, it should be integrated with a wide range of disciplines. Fourth, it is used to make the students improve in collaborative learning and solve the problem in the real world. Fifth, it can encourage the students work in groups and make a presentation.

Based on the prior observation at SMA N 1 Singaraja on Tuesday $23^{\text {rd }}$ February 2016, all of the English teachers are implementing Problem Based Learning model. This was done by doing an interview with all English teachers. Therefore this research is conducted to analyze the implementation of PBL in English language learning. This research is conducted in SMA N 1 Singaraja in academic year 2015/2016, because this school has been implemented the Curriculum 2013.

This research is focused on English language learning in relation to the importance of English as an international language. Therefore, this research is conducted to analyze the implementation of PBL in English language learning. This research is conducted in SMA N 1 Singaraja in academic year 2015/2016, because this school has been implemented the Curriculum 2013 and there are the problems in using Problem Based Learning model as stated in previously.

Previously, the researches about the implementation of problem based learning model were conducted by several researchers. Some of them are, Mulya, Adnan, \&Ardi (2013), entitled "The effect of Problem Based Learning model toward students speaking ability at the first grade of SMA N 1 EnamLingkung". In their research, the students get many opportunities to practice in small group such as practicing the pronunciation and also the dialogue that will be performed.

Furthermore, the research about Problem Based Learning by Dewi (2015), entitled "Analisispenerapan model Problem Based Learning dalam pembelajaranmenulistekslaporanhasilobservasikelas X IIS 1 SMA N 1 Mendoyo". In her research, Problem based learning model was successfully applied in X grade IIS 1 class at SMA N 1 Mendoyo. The reason is the teacher was able to stimulate the curiosity of students to the issues near and around the students.

The first research was focused on the effect of PBL in speaking ability and the second research was focused on writing skills. While this research focused on the English language learning. In this research, the researcher wants to analyze the implementation of PBL in learning English. Here she also wants to analyze the problem faced by the teacher as well as the students during the implementation of PBL in learning English. This research can contribute the consistency of the task with the Problem Based Learning model. 


\section{METHODS}

Based on the data, this research involved qualitative approach. The qualitative approach used to find out the implementation of Problem Based Learning in natural science in learning English at the XI grade class of SMA Negeri 1 Singaraja. The school that was chosen in this research is SMA Negeri 1 Singaraja. SMA N 1 Singaraja was chosen because this school is one of the senior high schools in Singarajathat continue implementing Curriculum 2013. The subjects of this research were the English teacher and 32 students of XI MIA 6 class. The object of this study was problem based learning. It is one of scientific methods which is recommended by curriculum 2013 that is implemented in teaching learning process in SMA N 1 Singaraja.

In collecting the data, the researcher used three methods namely, (1) observation method, usedtoobserve teaching and learning process, including the implementation of problem based learning in the classroom and to observe the problems that are faced by the teacher and the students during the teaching and learning process. This method used passive participant observation. The researcher was not the part of subject that was observed however the researcher only as the observer. (2) Interview method, used to analyze the teacher problems during the implementation problem based learning and to support the data that was collected from the observation. And (3)questionnaire method, used to collect the students' problems and response about the students' problems in implementing of PBL model and also to support the data that was collected from the observation. The questionnaire that used in this research adapted from the research journal of FauziahSulaiman, Hanafi Atan, Rozhan. M. Idrus, and HishamDzakaria in 2004. In 2011, this questionnaire was also used by Radzuwan AB. Rashid for his research. The questionnaire adapted from those researches because the condition and the situation of this research have a similarity with his research.

The data were analyzed descriptively through data reduction, data display, and conclusion drawing/verification by Mile \& Huberman (1994). In order to reach the validity and reliability of the data, the researcher used triangulation in this study.In this research, the researcher used data triangulation.

\section{FINDINGS AND DISCUSSION}

Based on the research design,the data gained from observation and then analyzed following the steps of data reduction, data display, and finally drawing conclusion/verifying. In the data reduction, the researcher selected and focusedto collect the data based on the focus of the study. The data were in the form of observation in the teaching and learning process in the classroom, the result of the questionnaire and interview with the subject of the study. Here are the findings and the discussion of this research.

\section{The Implementation of Problem Based Learning in Learning English}

Based on the finding gainded through the observation, the implementation of PBL in learning English by English teacher in SMA N 1 Singaraja has been implemented accordance with the PBL phases. The phases were: (1) Formulating the Problem, (2) Organizing the students to analyze the problem, (3) Helping the independent investigation and study in group, (4) Improving and presenting the discussion result, and (5) Analyzing and evaluating the process of solving the problem. 
In the first observation, the teacher gave analytical exposition text as a material of study. The topic used in this material was Global Warming. The teacher implemented 1 activity for every phases of Problem Based Learning. The problem used in this material ware cause - effect of Global and also made the solution to solve this phenomenon.

In the second observation, the teacher was given factual report text as a material of study. The topic used in this material was Factual Phenomenon. The teacher implemented 5 phases of Problem Based Learning with 3 activities in the $1^{\text {st }}$ phases, 2 activities in the $3^{\text {rd }}$ phases, 2 activities in the $4^{\text {th }}$ phases and only 1 activity in the $2^{\text {nd }}$ and $5^{\text {th }}$ phases. The problem used in this material were the students' should make a factual report text about animal or natural event and analyze the social function, the structure, and language features of factual report text in their group work.

In the last observation, the students' were given song by the English teacher as a learning material. The topic used in this material was English Song. Same as the previously observation, the teacher implemented 5 phases of Problem Based Learning with 3 activities in the $1^{\text {st }}$ phases, 2 activities in the $3^{\text {rd }}$ phases, 2 activities in the $4^{\text {th }}$ phases and only 1 activity in the $2^{\text {nd }}$ and $5^{\text {th }}$ phases. The problem used in this material were the students' should arrange the song lyric in their group discussion and analyze the lyric based on the structure of the song, social function, and the language elements of the lyrics. The title of song was "Like I would" from Zayn Malik. The students also listened to the music of that song during their arranged the song lyric in group work.

Based to the finding previously, the English teacher has already implemented Problem Based Learning process designed by Arend (2008). According to Arend (2008), PBL is a learning model that is designed to enable the students to discuss and solve the problems given by the teacher. There were some strengths and weaknesses in the implementation of PBL in learning English on XI MIA 6 used by the English teacher.

The first strength was this model could make the students interested and motivated. The second strength was PBL model emphasizes on the students ability in giving opinion or presenting the solution of the problems in front of the class. The third strength was the students can explore their knowledge to solve the problems and work on the task given by the teacher. The last strength was the students become more active in the learning process.

Those strengths were the same as the research conducted by Dewi (2015) and Mulya, Adnan, \&Ardi (2013). Based on Dewi's research, PBL model could make the students active in learning activity such as they have the curiosity with the issues near and around them, they have critical thinking by asking questions and solving the problem in group. Meanwhile Based on Mulya, Adnan, \&Ardi's research, PBL model could enable the students to interact and share their ideas in group.

However, based on the three observations conducted by the researcher from $18^{\text {th }}$ April 2016 until $2^{\text {nd }}$ May 2016, there were four weaknesses found in the implementation of Problem Based Learning. The first weakness was the tasks or problems given by the teacher were not suitable with Problem Based Learning model. Those tasks were in the $2^{\text {nd }}$ and $3^{\text {rd }}$ observations. In both of the observations, the teacher gave the task about writing a factual report text and arranging the song lyric. Both of the tasks were not suitable, because there was no problem that needs any solution.

The second weakness found in the observation was not all of the phases could run well in the implementation of Problem Based Learning model in the classroom. The 
phase that usually cannot run well is the fourth phase. In the fourth phase, not all groups can present their ideas about the solutions of global warming in front of the class because of the limited time in learning. Most of the time is allocated for the discussion session. The teacher gave ten minutes to every group in presentation.

The third weakness found in the observation was the lack of supporting books that can be used as an understanding in learning activities. In the implementation of Problem Based Learning, the English teacher only used one supporting book (LKS book) for each learning materials. This caused the problems for students in collecting the information to solve the problem about global warming. Besides that, it can influence the quality of problem solving that conducted by the students.

The last weakness found in the observation was the lack of student understanding about the problems given by the teacher. Those weaknesses were in line with the researches result found by Wijaya (2014) and Jayanthi (2015). Based on Wijaya's research, the teachers were not consistent in implementing Problem Based Learning model. In teaching processes, there were some activities that were not implemented by the English teachers. Meanwhile based on Jayanthi's research the students show a lack of understanding of the materials discussed and the teacher only uses one supporting book (bukupaket) for each learning materials. Those weaknesses were same as the theory from Wood (2004); in PBL model, the students need a certain book or need more than one book in their learning.

Based on the findings of this research, the teacher did not implement the second, the third, and the fourth characteristics of Problem Based Learning. The characteristics were the problems used cannot be well-structured, it should be integrated with wide range disciplines and make the students improving in collaborative learning and solve the problem in the real world. Tough, it should be all implemented by the teacher in order to maintain the students' self-learning and create the students as the problem solver.

\section{Problems faced by the teacher during the implementation of Problem Based Learning}

After all of the observations were done, the next activity was interviewing the English teacher Mrs. LuhPutu Indah Citra DewiS.Pd. This interview purposed to get the data about the problems that are faced by the teacher during the implementation of Problem Based Learning model in learning English. Here are the results of interviews with Mrs. LuhPutu Indah Citra Dewi, S.Pd that combined with the observation. The problems facedby the teacher not only came from the teacher but also from the students and the class facility.

From the teacher, she said it was difficult for her to determine the interesting topic for the students and need more time in implemented this model. From the students, Mrs. Indah said the ability of the students' is still weak in using thinking skills to solve a problem. For example there are some students who are still hesitant in expressing opinions. And the last was the problem came from the class facility. She said the facility was the classroom is not too weight, while in this class consists of 32 students. It made the teacher could not be mobile all of the students in group discussion activity because the seating positions much have changed.

Based on the finding previously, the problems that are faced from Mrs. Indah as an English teacher were come from herself (teacher), students, and the facility. The First was the teacher still difficult to determine the topic and needs more allocation time. 
According to Wood (2004), one of the disadvantages in implementing PBL model is takes a long time to implement. It is the same as the research that was conducted by Dewi (2015). Based on Dewi's research, the teacher needs more time in teaching used PBL model. In this case, the teacher should manage the allocation time in learning and prepared the learning materials accordance with the allocation time that has been prepared.

The second was the teacher felt not all the students want to express their opinion. The last problem was the facility. The classroom is not too weight, It made the teacher could not be mobile all of the students in group discussion activity because the seating positions much have changed.

The second problem was same as the research that was conducted by Somodana (2015). Based on Somodana's research, there are still students who are less able to think critically, which is the ability is important in problem-based learning. In this problem, the teacher should use a certain way to make the students able to think critically in the class. Such us: determining the interesting topic or determining the interesting problem.

The last problem was same as the research that was conducted by Jayanthi (2015). Based on Jayanthi's research,the classroom is not too large and not suitable to role play activity. In this case, the teacher should use a certain way. Such us: shifting the students chair when they are discuss.

\section{Problems faced by the students' during the implementation of Problem Based Learning}

To know the students' problems, the researcher used the questionnaire. Then, the researcher compared the questionnaire result with the observation result to get the relevant finding. That finding can be seen from the table below:

Table 1. The result finding of the Problem that faced by the Students

\begin{tabular}{llll}
\hline No. & Observations & Questionnaire & Finding \\
\hline 1. & $\begin{array}{l}\text { There were } \\
\text { some students } \\
\text { who are still } \\
\text { hesitant in } \\
\text { expressing their } \\
\text { opinion. }\end{array}$ & $\begin{array}{l}\text { 25\% the } \\
\text { students doubt } \\
\text { to identify the } \\
\text { issues that } \\
\text { require critical } \\
\text { thinking to } \\
\text { understand. }\end{array}$ & $\begin{array}{l}\text { The students were } \\
\text { still weak in } \\
\text { improve in } \\
\text { collaborative } \\
\text { learning and solve } \\
\text { the problem in the } \\
\text { real world. }\end{array}$ \\
& $\begin{array}{l}\text { 3 students } \\
(9,37 \%) \text { doubt } \\
\text { about the } \\
\text { ability to } \\
\text { understand the } \\
\text { material that } \\
\text { they observed. }\end{array}$ & $\begin{array}{l}\text { The students were } \\
\text { doubt about PBL } \\
\text { model made they } \\
\text { have the ability to } \\
\text { understand the } \\
\text { material that they } \\
\text { observed. }\end{array}$ \\
& &
\end{tabular}

From the table 1 showed, The first problem from the questionnaire was the students felt in doubt that PBL model made them easy to understand the material which they learned. The second problem was the students' were hesitant to identify the issues that require critical thinking to understand. 
Based on the finding previously, the first problem from the questionnaire was the students felt in doubt that PBL model made them easy to understand the material which they learned. Here, when the students didn't understand the lesson, the students' were not able to identify the problem.

The second problem was the students' were hesitant to identify the issues that require critical thinking to understand. Those problems were the same as the research conducted by Somodana (2015). Based on Somodana's research, some students were less able to think critically, which is the important ability in Problem Based Learning. It can be said, one of the characteristics in Problem Based Learning was still not achieved. The characteristic is to make the students improve in collaborative learning and solve the problem in the real world. Because according to Kemendikbud, it refers to the fourth of the characteristic in Problem Based Learning model.

\section{CONCLUSION}

Based on the research findings discussed in the previous chapter, it is concluded that Problem Based Learning should be conducted in teaching and learning English. The reason is through this model, the students' have the opportunity to practice their critical thinking, self-directed learning, discussion in group work, and share their opinion. Meanwhile, For other researcher who want to make the same research, should be able to explore more information and explanation about problem based learning model.

\section{REFFERENCES}

Arends. (2008). Learning to teach-belajaruntukmengajar. Yogyakarta: Pustaka Belajar (translated by Helly Prajjitno Soetjipto and Sri Mulyantini Soetjipto)

Dewi, N.P.E.P. (2015). Analisis Penerapan Model Problem Based Learning dalam

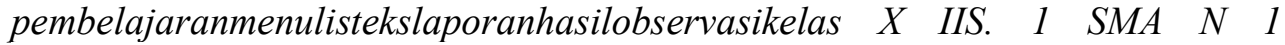
Mendoyo. (unpublished thesis). Pendidikan Bahasa dan Sastra Indonesia. Fakultas Bahasa danSeni. UndikshaSingaraja.

Jayanthi, N. T. P., (2015). Penerapan Strategi Pembelajaran Berbasis Masalah dalam PembelajaranBermainPeranpadaSiswaKelas VIII SMP Negeri 5 Amlapura. (Unpublished Thesis). Pendidikan Bahasa dan Sastra Indonesia. Fakultas Bahasa dan Seni. UndikshaSingaraja.

Kadir. Z. B. A., (2013). Enhancing Students' Problem Solving Skills using PBL as an Instructional Communication Approach. (Publish Thesis). Graduate Studies. Putra Malaysia University. Retrived January 4, 2016 from: http://eprints.uthm.edu.my/4660/1/zulida_abdul_kadir.pdf

Kemendikbud. (2014). MateriPelatihan Guru ImplementasiKurrikulum 2013 TahunAjaran

2014/2015.BadanPengembanganSumberDayaManusiaPendidikandanKebudayaa ndanPenjaminanMutuPendidikan: Jakarta

Miles, M.B. \& Huberman, A.M. (1994). Qualitative data analysis and Expanded Source Book. London: Sage.

Mulya, R.A., Adnan, A., \&Ardi, H. (2013). The effect of Problem Based Learning strategy toward students speaking ability at the first grade of SMA N 1 EnamLingkung. Journal of English language teaching, 2, 1-10. Retrived January 3, 2016 from: http://ejournal.unp.ac.id/index.php/jelt/article/download/2619/2219 
Sukraningsih, G.A.G. (2015). The Implementation of Scientific Approach in English teaching based on Curriculum 2013 to tenth grade students of SMA N 1 Denpasar. (unpublished thesis). English language education. Postgraduate Program. UndikshaSingaraja.

Sulaiman, F., Atan, H., Idrus, R. M., \&Dzakaria. H. (2004). Problem-based learning: A study of the web-based synchronous collaboration. Malaysian Online Journal of Instructional Technology. 1 (2), 1-9. Retrived April 26, 2016 from: https://www.researchgate.net/publication/228956317_Problem_Basd_Learning A Study of the WebBased_Synchronous Collaboration

Somodana, W. (2015). Penerapan model PembelajaranBerbasisMasalah (PBL) dalam pembelajaranmenulisanekdotsiswakelas $X$ SMA Negeri 3 Singaraja. (unpublished thesis). Pendidikan Bahasa dan Sastra Indonesia. Fakultas Bahasa danSeni. UndikshaSingaraja.

Thomas, K. (2013). Problem Based Learning. Qwest, 1-29. Retrived January 3, 2016 from :http://www.rockymountainalchemy.com/whitePapers/wp-problem-basedlearning-overview-qwest.pdf

Wicaksono, Lugas. (2014). 20 Sekolah di BulelengtetapterapkanKurikulum 2013.Tribun Bali. Retrieved December 22, 2015 from: http://bali.tribunnews.com/2014/12/22/20-sekolah-di-buleleng-tetap-terapkankurikulum-2013

Wijaya, E.W.N. (2014). Analysis the implementation of Problem Based Learning in English teaching learning processes based lesson plans at SMP Nesgeri 2 Amlapura. (Unpublished Thesis). English education department program, Faculty of languages and arts, UndikshaSingaraja.

Wood, E. (2004). Problem Based Learning. ActaBiochimicaPolonica. 51, 1-6. Retrieved January 4, 2016 from: http://www.actabp.pl/pdf/2 2004/XXI.pdf

Yasmin, Yulfika. (2009). Penerapan Problem Based Learning untukMeningkatkanMotivasidanHasilBelajar Dalam Pembelajaran Bahasa Indonesia SiswaKelas $V$ SDN Tegalweru. (Published Thesis). JurusanKependidikanSekolahDasardanPrasekolah, FIP, UniversitasNegeri Malang. Retrieved December 24, 2015 from: http://karyailmiah.um.ac.id/index.php/KSDP/article/view/4340

Yuan, H., Kunaviktikul, W., Klunklin, A., \& Williams, B. A. (2008). Promoting Critical Thinking Skills Through Problem-Based Learning. CMU. Journal of Soc. Sci. and Human. 2, 85-100. Retrieved March 30, 2016 from: http://cmuj.cmu.ac.th/sites/default/files/pdf/SocialSciencesandHumanities/Volu me\%202\%20June\%202008\%20Number\%201/05\%20Journal\%20Social.pdfZeig er, S. (2013). What is the role teacher in education?. Chron. Retrived January 4, 2016 from :http://work.chron.com/role-teachers-education-8807.html

Zulyetti. (2015). Pendekatan Saintifik untuk Pengajaran Bahasa Inggris PadaKurikulum 2013. LPMP Propinsi Riau. Retrieved Juni 24, 2016 from :http://pmpriau.go.id/?p=742 